\title{
NIH bucks political trend to win increased funds from Congress
}

Washington. A subcommittee of the US House of Representatives last week approved a generous increase in funding for the National Institutes of Health (NIH) next year. If eventually approved by Congress, this would result in an increase of almost seven per cent for the biomedical agency, at a time when dozens of other government programmes are having their funds cut.

The proposed increase comes from the subcommittee on labour, health and human services and education of the House Appropriations Committee, which early last Friday (14 June) passed a spending bill for the fiscal year 1997, raising NIH funding by $\$ 820$ million - or 6.9 per cent - from $\$ 11.9$ billion in 1996 to $\$ 12.7$ billion in 1997 .

In a surprise move, the Republicandominated subcommittee also removed a provision extending a ban on government funding of human embryo research.

The bill includes $\$ 90$ million for a new 250-bed Clinical Research Center (CRC) planned for the NIH campus, considerably less than the $\$ 310$ million requested by the Clinton administration. But it increases the rest of NIH funding, most of which is spent on research, by 6.5 per cent, $\$ 765$ million above the 1996 level.

The increase is allocated fairly evenly across the NIH institutes. The two largest - the National Cancer Institute and the National Heart, Lung and Blood Institute - would both receive increases of 6.1 per cent, while the National Institute of Allergy and Infectious Diseases would see its budget grow by 7.5 per cent, well above the anticipated rate of inflation.

Harold Varmus, the director of NIH, was cautious in welcoming the subcommittee's decision to increase the research budget. "It's a pleasing number, but it's only the first step in the process," he said on Monday.

In contrast, Ralph Bradshaw, president of the Federation of American Societies for Experimental Biology, which has lobbied hard for increased funding for biomedical research, said his organizations were "really very, very pleased". The proposed 6.5 per cent increase would make things "as rosy as they have been at the NIH for some time".

Few other agencies in the $\$ 65.7$-billion bill passed by the subcommittee, which funds three major government departments, benefited from the largesse showed towards the NIH. This prompted complaints from liberal Democrats that other programmes, such as education, had suffered as a result.

But John Porter (Republican, Illinois), chairman of the subcommittee, defended
NIH's allocation. "It's something only government can do. There's no profit motive in basic research," he said. "It pays for itself in terms of health care cost savings thousands of times over. It's perhaps the most efficient spending government ever does."

The bill will become law only after it has been approved by the full House Appropriations Committee, the full House, parallel Senate bodies and President Bill Clinton. But the NIH funding increase, largely the work of Porter, is expected to set the

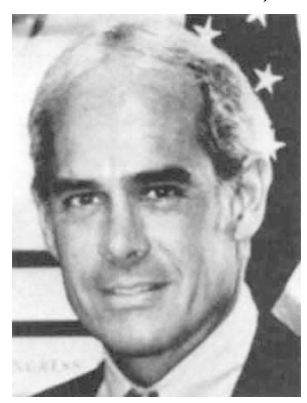

Porter: praised costeffective work by NIH. mould for House legislators.

The reversal of the ban on NIH funding for human embryo research was passed by nine votes to four, with Porter and three other Republicans joining Democrats on the subcommittee to end the ban. Porter cited recent testimony by Eric Wieschaus of Princeton University, a co-winner of last year's Nobel prize for physiology or medicine, in arguing for the ban's reversal.

If the reversal is maintained, the ban would be lifted from the beginning of the fiscal year on 1 October. But the author of the current ban, Jay Dickey (Republican, Arkansas), vowed to reinsert it in the bill at the full Appropriations Committee.

In a separate vote, the subcommittee defeated a bid by Democrats to give back to the Office of AIDS Research (OAR) full control over the money spent by NIH on AIDS research, $\$ 1.4$ billion in the current fiscal year. The Democratic attempt, if successful, would have given the OAR the power to distribute directly the huge AIDS research budget to the NIH's 24 institutes, centres and divisions.

This power is mandated by a 1993 law authorizing the NIH budget, but is not currently in place, as Republicans circumvented it in a 1996 spending bill. The effort to restore a 'consolidated' budget to the OAR, introduced as an amendment by Nancy Pelosi (Democrat, California), was defeated by nine votes to five, the subcommittee splitting along party lines.

After the vote, Mark Harrington of the Treatment Action Group, an AIDS advocacy group, complained that the question of the OAR's authority had become "a political football". He pointed out that in March, a 118-member expert panel chaired by Arnold Levine of Princeton University had recommended that the OAR retain its fund-distributing duties.

Other AIDS activists said that implementation of Levine's report on restructuring AIDS research at NIH would be badly damaged if the subcommittee's decision stands. "Without budget authority [for OAR] the Levine committee report is waste paper," said Gary Rose, of the AIDS Action Council, which is based in Washington, DC.

But Levine himself disputed that. "I don't believe that the implementation ... of our report [depends] on a consolidated budget," he says.

\section{Japan puts a twist in fusion efforts}

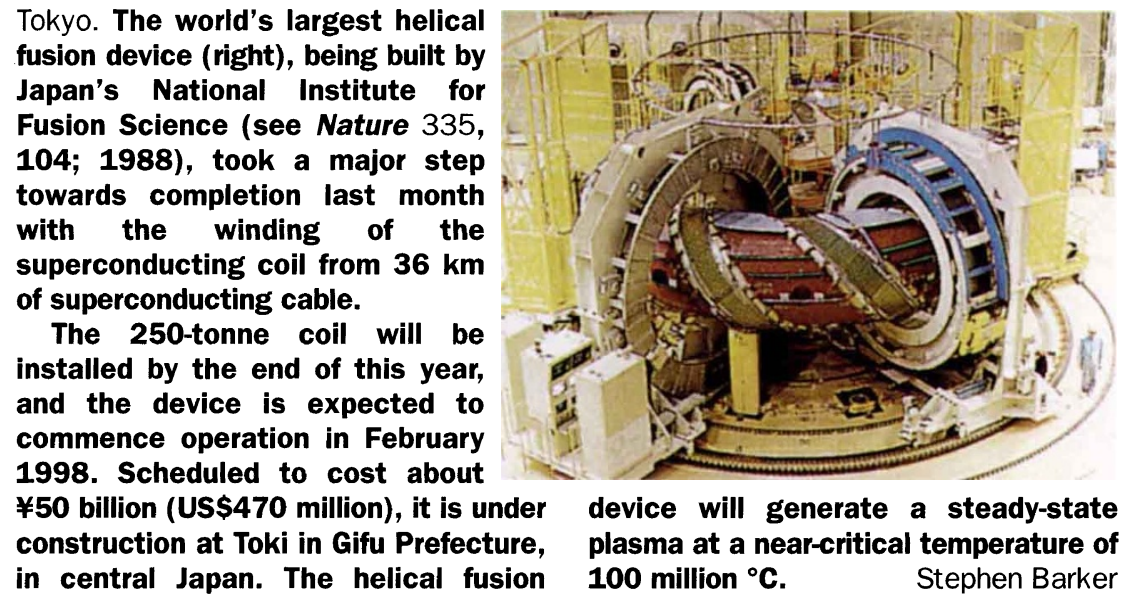

